\title{
An OTEC Annual Report to the Division of Solar Energy for FY-1976 and the Transition Quarter
}

December 1976

Prepared for the Energy Research and Development Administration under Contract E(45-1)-1830 


\section{NOTICE}

This report was prepared as an account of work sponsored by the United States Government. Neither the United States nor the Energy Research and Development Administration, nor any of their employees, nor any of their contractors, subcontractors, or their employees, makes any warranty, express or implied, or assumes any legal liability or responsibility for the accuracy, completeness or usefulness of any information, apparatus, product or process disclosed, or represents that its use would not infringe privately owned rights

\section{PACIFIC NORTHWEST LABORATORY operated by \\ BATTELLE \\ for the}

\section{ENERGY RESEARCH AND DEVELOPMENT ADMINISTRATION} Under Contract EY-76-C-06-1830

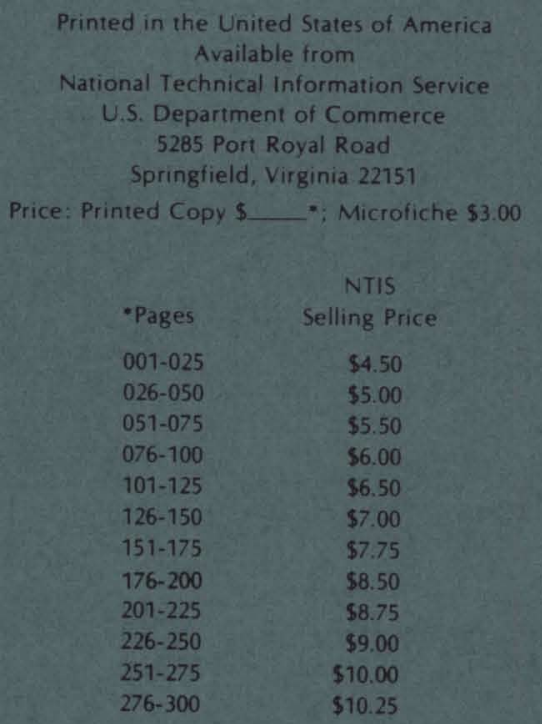




\section{9}

AN OTEC ANNUAL REPORT

TO THE DIVISION OF SOLAR ENERGY FOR

FY-1976 AND THE TRANSITION QUARTER

by

Lyle D. Perrigo

George A. Jensen

November 1976

BATTELLE

Pacific Northwest Laboratories

Richland, Washington 99352 

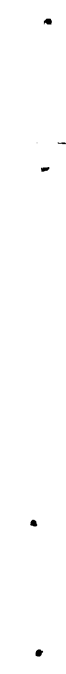


\section{SUMMARY}

The Ocean Thermal Energy Conversion (OTEC) Program, Biofouling and Corrosion Activity Office, was initially designed to plan a program to identify, control, and alleviate biofouling problems that may be found in the operation of OTEC systems. The scope of the program was subsequently expanded to include project development and monitoring activities in marine corrosion as well as those needed for the proper solution of any biofouling problems that might be encountered in OTEC systems. This report describes work conducted from January to September 30, 1976.

Although numerous projects have been funded, only three have been underway for a sufficient length of time to have generated an apppreciable amount of information. One project at Carnegie-Mellon University has resulted in the development of a device to measure the effects of the very thin films that are expected to be the controlling variable in the operating efficiency of OTEC heat exchangers.

Another program conducted by Alcoa determined that surface area-tovolume was not likely to be a major corrosion variable for aluminum in ammonia contaminated with seawater. 


\section{CONTENTS}

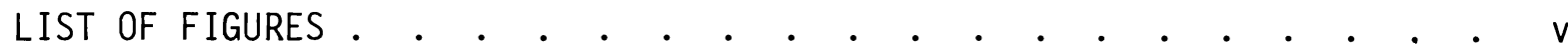

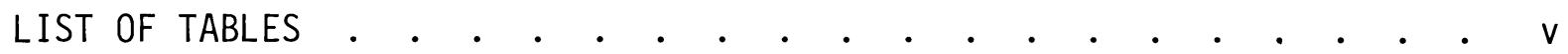

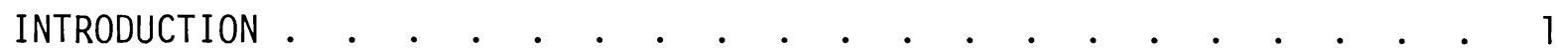
TECHNICAL PROGRAM . . . . . . . . . . . . . . . . . . 3

METHODOLOGY. . . . . . . . . . . . . . . . . . . . 3

Problem Definition. . . . . . . . . . . . . . . . . 4

Preventative Measures. . . . . . . . . . . . . . . 6

Alleviation Measures. . . . . . . . . . . . . . . . 7

FY-1976 AND TRANSITION QUARTER PROJECT WORK . . . . . . . . . 9

Follow-On Projects. . . . . . . . . . . . . . . . 10

Unsolicited Project Proposals . . . . . . . . . . . . 12

Newly Developed Projects. . . . . . . . . . . . . . . 12

TECHNICAL ACCOMPLISHMENTS . . . . . . . . . . . . . . . . . 14

Development and Use of a Biofouling and Corrosion Measuring Device.. . . . . . . . . . . . . . 14

Aluminum-Ammonia-Seawater Corrosion . . . . . . . . . . 20

Development of Low Energy Surfaces . . . . . . . . . . . 23

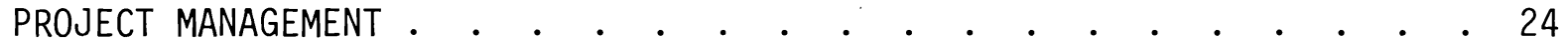

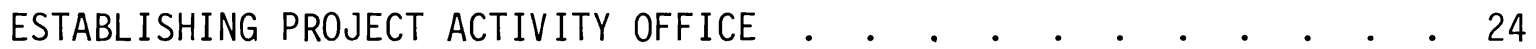

PERSONNEL ACQUISITION $\cdot$.

PROJECT DEVELOPMENT . . . . . . . . . . . . . . . . . . . 29

Project Development Procedures. . . . . . . . . . . . . 29

Definition and Selection. . . . . . . . . . . . . 31

Ongoing Project Development Activities . . . . . . . . . 34

PROJECT EVALUATION AND CONTROL PROCEDURES. . . . . . . . . . 36

BUDGETS AND COSTS. • . . . . . . . . . . . . . . . . 37

TECHNOLOGY TRANSFER . . . . . . . . . . . . . . . . . 38

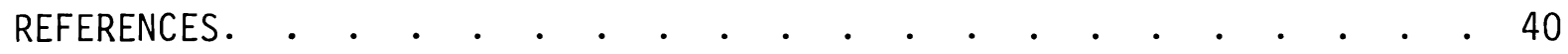

DISTRIBUTION . . . . . . . . . . . . . . . . . . . . . Distr-1 


\section{LIST OF FIGURES}

1 Methodology for OTEC Biofouling and Corrosion

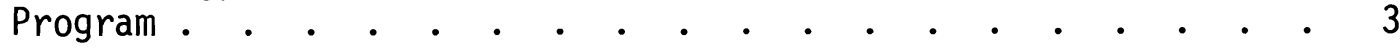

2 Tube with Instrumentation . . . . . . . . . . . 16

3 Decay of Temperature with Time . . . . . . . . . . . 17

4 Variation of $1 / \mathrm{h}$ with $1 / \mathrm{v}^{0.8}$. . . . . . . . . . . . 17

5 Thermal Resistance Due to Biofouling and Corrosion

Product . . . . . . . . . . . . . . . . . 20

6 Corrosion of 1100 Alloy in Ammonia - Deionized/

Seawater Solutions . . . . . . . . . . . . . 22

7 OTEC Organization. . . . . . . . . . . . . . . . 25

8 Department Organization. . . . . . . . . . . . . . 25

9 OTEC Communications . . . . . . . . . . . . . . . 26

10 Biofouling and Corrosion Project Organization . . . . . . 28

11 Joint Functions . . . . . . . . . . . . . . . . 28

12 Project Development . . . . . . . . . . . . . 30

13 Proposal Development. . . . . . . . . . . . . 30

14 Proposal Request Development . . . . . . . . . . 31

15 Methodology Reconciliation. . . . . . . . . . . . . 35

16 Budgets . . . . . . . . . . . . . . . . . . . 37

\section{LIST OF TABLES}

1 Nominal Flow Velocity: $3 \mathrm{ft} / \mathrm{sec}$, Material: Al 6061-T6

(Tube No. 1) . . . . . . . . . . . . . . . . . 19

2 Nominal Flow Velocity: $6 \mathrm{ft} / \mathrm{sec}$, Material: Al 6061-T6

(Tube No. 2) . . . . . . . . . . . . . . . . 19

3 Rate and Type of Attack Information. . . . . . . . . 22

4 Projects Needed to Define, Prevent, and Alleviate

OTEC Biofouling and Corrosion Problems. . . . . . . . 32

5 Additional Projects Needed as Defined at the Monterey, California Meeting 


\author{
AN OTEC ANNUAL REPORT \\ TO THE DIVISION OF SOLAR ENERGY \\ FOR FY-1976 AND THE TRANSITION QUARTER
}

OCEAN THERMAL ENERGY CONVERSION BIOFOULING AND CORROSION STUDY

\begin{abstract}
Biofouling and corrosion of the heat transfer surfaces in Ocean Thermal Energy Conversion (OTEC) systems are believed to be controlling factors in the potential success of the OTEC concept. The purpose of the OTEC program in biofouling and corrosion research and development is to provide for: 1) the necessary work to define, prevent, and alleviate biofouling and corrosion problems associated with OTEC systems, and 2) the proper management of various projects that should be undertaken in this area to achieve program objectives.
\end{abstract}

\title{
INTRODUCTION
}

In December 1975 the Division of Solar Energy, Energy Research and Development Administration (ERDA), authorized the Pacific Northwest Laboratories (PNL, Battelle Memorial Institute) on its prime contract with ERDA to help in planning a program to identify, control, and alleviate biofouling problems that may be found in the operation of Ocean Thermal Energy Conversion (OTEC) systems. Subsequently, the scope of the PNL effort was expanded to include project development and monitoring activities in marine corrosion as well as those needed for the proper solution of any biofouling problems that might be encountered in OTEC systems.

The effort at PNL is part of a larger program conducted by the Division of Solar Energy to explore the feasibility of the OTEC concept. This concept involves the use of a temperature difference between the warm surface and cold, deep waters in the Tropics to drive a heat engine to produce electricity. With favorable developments this concept might furnish as much as 4 to $6 \%$ of the total anticipated U.S. energy demand in the year 2020. The possibility of the OTEC concept being an alternative source of 
energy provides the stimulus for a thorough examination of the factors affecting the use of the oceans for the beneficial purpose of generating electricity.

This report details PNL efforts in assisting ERDA with the planning, development and monitoring of projects to define, control and alleviate biofouling and corrosion problems that may be found in OTEC systems. It contains information on PNL activities from January through September, 1976. The Schedule 189 provides funds for the operation of the PNL effort and attendant reporting requirements calling for annual reports. We are forwarding our first annual report to cover the work undertaken in the fiscal period ending September 30, 1976. No quarterly report is planned for the period July through September 1976; information on biofouling and corrosion project activities in those months is covered in this report. 


\section{TECHNICAL PROGRAM}

Information on the technical program effort by the Biofouling and Corrosion Project Activity Office for the reporting period January through September 1976 will be presented in three subsections. The first subsection deals with the methodology used to guide the technical efforts of the project activity office during its period of startup and before a detailed master plan is developed and approved. The second subsection describes the projects developed for funding in FY-1976 and the rationale for their selection. The final subsection presents a summary of significant technical information obtained from various projects.

\section{METHODOLOGY}

The methodology to direct R\&D efforts on Ocean Thermal Energy Conversion (OTEC) biofouling and corrosion problems is shown in Figure 1. The overall effort is comprised of three major elements concerned with problem definition, preventative techniques, and methods for overcoming deleterious biofouling and corrosion in operating systems. Each of the major elements

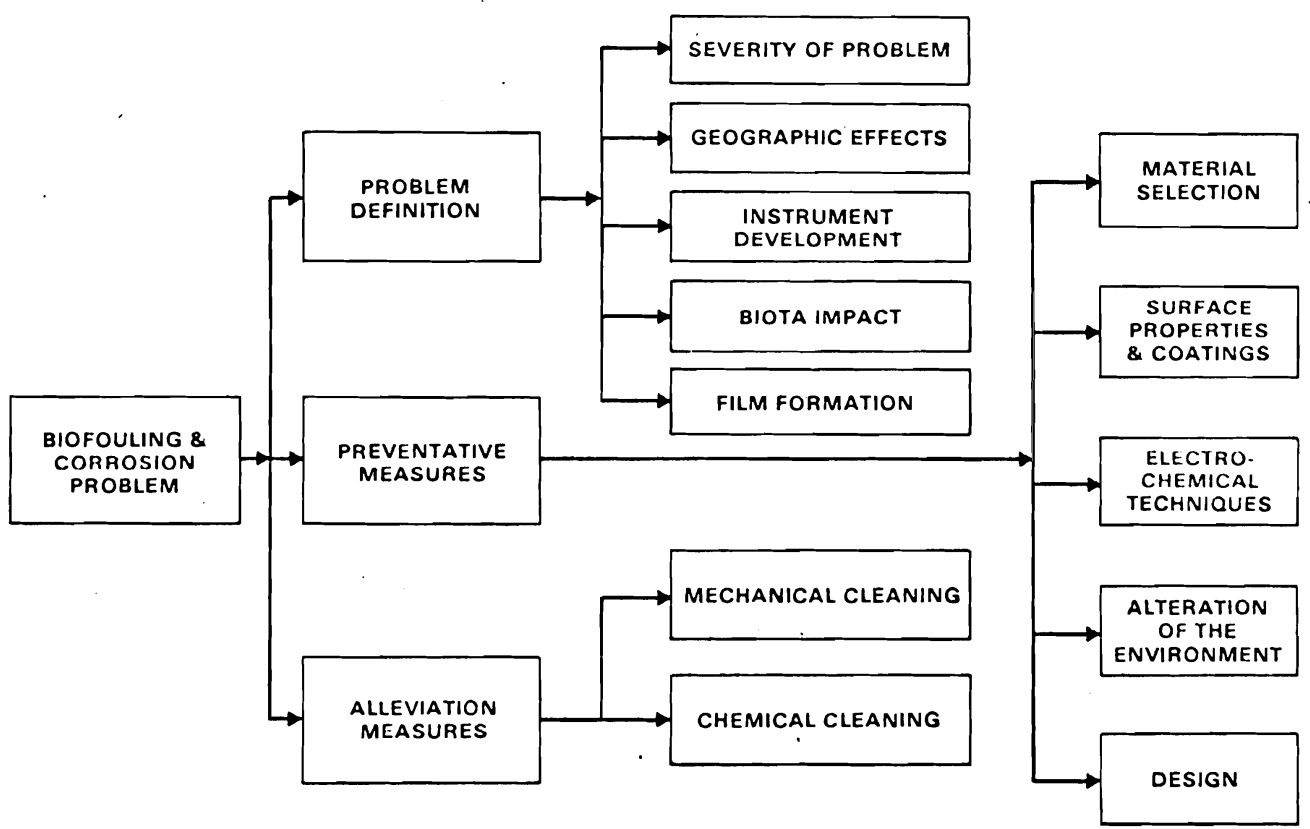

FIGURE 1. Methodology for OTEC Biofouling and Corrosion Program 
consists of several subelements dealing with specific approaches to/or methods for solving the allied problems of biofouling and corrosion in OTEC systems. More detailed information on each of the major project elements and its constituent parts are described in the following subsections.

Problem Definition

The proposed program contains a substantial effort in defining the nature and extent of biofouling and corrosion because little information is available on the nature and extent of biofouling or corrosion for many of the conditions under which an OTEC unit would operate. It is acknowledged that there is a wealth of data available on biofouling and corrosion of various materials and systems in coastal waters and harbors. However, since the systems may operate in mid-ocean, there may be considerably different and perhaps less problems for OTEC systems. Another important consideration is the cold, deeper ocean waters that will be employed as the heat sink for the OTEC system. Little is known about the biofouling or corrosion potential of such waters or about the perturbation effect of the OTEC system on mid-ocean biota, which will also be examined. Since biofouling and corrosion are critical path items for the OTEC system, the following definitional studies will be required to achieve mission objectives.

- Severity Studies. The unknown effects of biofouling and corrosion in mid-ocean and with surface and deep, cold ocean waters are to be defined by a number of key experiments.

- Geographic Effects. Appreciable uncertainty exists within the scientific and technical community about both the relative effects of biofouling and the allied corrosion problems in different geographic areas that might employ OTEC systems. Work in this sector will be focused on defining differences, if any, for the areas of interest to the United States.

- Instrument Development. At the present time, there is one design for a device to measure the biofouling and corrosion effects in ocean waters potentially applicable to OTEC. There are, however, only limited operating data in an ocean environment showing that this device 
will provide the information needed for the program. Effort will be applied to provide the necessary testing capability required to define the severity of the biofouling and corrosion problem. Additional test instruments will be developed, tested, and evaluated to obtain corroborating measurements of the biofouling and corrosion effects of ocean waters where OTEC systems may be located.

- Biota Impact. The water taken from the cold strata deeper in the ocean is likely to be richer in nutrients than the surface or nearsurface waters, where the OTEC system is expected to be located. Since pumping these nutrients closer to the surface is expected to have a significant effect on the abundance of flora and fauna in and adjacent to the OTEC system, the impact of this effect must be defined including aspects pertaining directly to OTEC heat transfer surfaces. The impact of OTEC system operations on the environment must also be assessed. For example, in chemical cleaning the release of chemicals or other cleaning products may be detrimental to the biota in the waters surrounding the OTEC system. The effects of low concentrations of heavy metals and even chlorine on biota in OTEC locations, for example, may be severe and must be defined.

- Film Formation. Organic chemicals, such as proteins, wastes from biological species, and decomposition residues exist in seawater. Many of these materials can precipitate on all surfaces exposed to seawater in the OTEC system. In particular, the formation of a film as little as 0.010-in. thick on the heat transfer surface can reduce heat transfer by a minimum of $50 \%$. The rate, character, and composition of $f i 1 m$ formation in areas where OTEC systems are to be located must be identified, particularly the rate of formation, composition, and thickness of films forming on heat transfer surfaces. These films may also cause corrosion of the materials used in the construction of heat transfer surfaces. The corrosion effects of these films on the materials proposed for UTEC heat exchanger surfaces and biota impact of the film on these materials will also be investigated. 


\section{Preventative Measures}

A number of measures have been used to a greater or lesser extent in the past several decades to prevent or reduce the unfavorable effects of biofouling and/or corrosion. In this program, these preventative procedures are to be examined to determine their merits in coping with OTEC biofouling and corrosion problems. The existing and substantial technology base in this area will be used as the starting point for work in this sector. Details on specific fields of study follow.

- Material Selection. Certain materials are known to suffer less biofouling and corrosion in coastal and harbor waters than others. The OTEC biofouling and corrosion tendency of these and other candidate materials will be examined in this portion of the study. An important consideration in selecting candidate materials for such examinations is their availability in the amounts needed for OTEC systems and their economics compared with competitive materials.

- Surface Properties and Coatings. One of the methods to avoid or minimize biofouling and corrosion problems is to provide for:

1) special surface conditions, or 2) coatings that will impede/ inhibit undesirable effects. Work in this area will be focused on an examination of what, how, and if these techniques may be applied beneficially to OTEC systems.

- Electrochemical Techniques. The application of electrochemical procedures is one of the classical approaches to the prevention of corrosion on a wide variety of systems in a number of environments. The examination of the feasibility of using this approach to avoid biofouling and corrosion in OTEC systems is expected to be one of the techniques studied in this program.

- Alteration of the Environment. Alteration of the environment is terminology used by corrosion engineers to describe procedures for changing the corrosive nature of the medium in which materials are exposed. Careful examination of this approach to minimize or avoid biofouling and corrosion problems in OTEC systems is warranted. 
Some discussion has already been directed toward the possible use of chlorine to impede-inhibit biofouling of OTEC systems. Effort in this sector of the project will be focused on examining the feasibility and desirability of using chlorine to solve the biofouling problem as well as other potentially useful techniques of this nature that would have a beneficial impact. The effects of these methods and their corrosion potential will also be evaluated.

- Design. One of the wel1-accepted methods for preventing or minimizing corrosion is to design the plant to avoid conditions that accelerate or initiate such undesirable effects. A similar set of conditions may be possible for biofouling and will be examined in this proposed study. It should be recognized that design as a preventative measure is markedly different from design in its usual sense. Antibiofouling and corrosion design is concerned with the effects of geometry, orientation, layout, relative location, configuration, fluid flow characteristics, etc., and not specific plans for particular pieces of hardware or facilities. It impacts the latter by indicating favorable or unfavorable conditions of design. Although well recognized as a corrosion prevention technique, it has not been widely used because few people know enough about anti-corrosion design principles to effectively apply the method. However, these techniques are straightforward and are proposed for study as another means of avoiding biofouling and corrosion problems.

\section{Alleviation Measures}

A number of simple as well as more sophisticated measures are routinely used to remove biofouling buildup and corrosion films from marine heat transfer and other surfaces. Current technology involves both mechanical and chemical methods to accomplish this. Ideally, a combination of conditions, preventative measures, and operational techniques would avoid biofouling and deleterious corrosion effects in OTEC systems. Practical1y, however, the optional combination of variables will merely minimize these 
undesirable effects. It then becomes a matter of providing cleaning procedures, that might be online, or shutdown techniques, that might maintain heat transfer and other surfaces in an optimal state of cleanliness, so that the OTEC mission may be achieved. This portion of the project is focused on measures that will provide this optimal level of system cleanliness.

- Mechanical Cleaning. One mechanical method for possibly maintaining desired cleanliness of heat transfer surfaces in OTEC systems has already been considered on a conceptual basis. A proprietary method reportedly uses soft rubber balls that are frequently fed into various tubes in a heat exchanger to wipe undesirable substances from these surfaces. A second method uses cavitation in a hydraulic system to remove undesirable materials from surfaces. These are two of many procedures that should be examined, some of which will be procedures for the heat source, as well as the heat sink side of the OTEC Plant.

Key factors that should be evaluated in the development and selection of any candidate mechanical cleaning method as well as a chemical method are: 1) the long-term effectiveness in maintaining desired surface conditions, 2) erosion/corrosion/defilming effects that may result from cyclical use of cleaning methods, 3 ) the need/ desirability of having multiple cleaning options to beneficially supplement each other to achieve desired conditions, and 4) operational versus shut-down methods to maintain desired conditions.

- Chemical Cleaning. As with mechanical cleaning procedures, there are many chemical cleaning methods that potentially could be used for maintaining the proper surface conditions in OTEC systems. Viable procedures should be identified, examined, and developed for this particular application. An important consideration in the development of a useful chemical process will be the handling and disposal of the cleaning medium after it is used. The key factors involved in the selection of viable cleaning processes mentioned in the previous subsection also apply to chemical cleaning and are considered integral and necessary parts of this study. 
FY-1976 AND TRANSITION QUARTER PROJECT WORK

Biofouling and corrosion project development activities for FY-1976 were concerned with three types of projects. The first type was the followon projects to exploit or carry through interesting work that had been initiated earlier by the OTEC Branch, Division of Solar Energy. It will be the subject of the first of three subdivisions under this heading. The next part of our FY-1976 project development work was directed toward unsolicited proposals (discussed in the second subsection). Before proceeding further in this discussion it should be remembered that all comments on FY-1976 Project Work are directed solely to projects that were assigned to or funded by FY-1976 and Transition Quarter monies allocated to the Biofouling and Corrosion Project Activity Office. Since the project activity office started operation on January 1, 1976 and the necessary procurement operations needed to acquire contracts with qualified and interested organizations takes an appreciable amount of time, our report on FY-1976 Project Development will be generally limited to a discussion of what these projects were, the funds obligated for these projects, and the limited information available from two experimental efforts. Funds were obligated so they would be available in the final months of CY-1976 and later for work on various projects initiated in FY-1976. How these obligated funds are to be used will be treated in the third subsection.

Another important point to be made on FY-1976 projects developed by the Biofouling and Corrosion Project Activity Office concerns the processes by which they were initiated. They were carefully evaluated or developed by a panel of consultants assisting the Biofouling and Corrosion Project Activity Office. This panel of experts met twice to examine or identify projects needed to define, control and alleviate biofouling and corrosion problems that are anticipated to have a major impact on the operation of the OTEC systems. In addition, most of these consultants were involved in preparing project work statements and evaluating RFP responses received by the project activity office. The use of a group of experts to help in these areas was considered to be desirable to ensure that quality projects were developed to give the comprehensive scientific and technical coverage needed to achieve the objectives of the project activity office in a timely and cost effective manner. 
Follow-On Projects

There were three projects underway or assigned to the Biofouling and Corrosion Project Activity Office in FY-1976 that were primarily concerned with biofouling and corrosion. Another project concerned with OTEC heat transfer technology had a corrosion task. Further information follows in four subsections.

Development and Use of Biofouling and Corrosion Measuring Device

The National Science Foundation (NSF) funded a \$160,106 project at Carnegie Mellon University (CMU) in 1975 entitled "A Study of Fouling and Corrosion Problems in a Solar Sea Power Plant". Initial work was directed toward developing a device to measure the buildup of microfouling and corrosion product films in situ by monitoring temperature decay in a tube that is periodically heated. Dr. John G. Fetkovich, who was the principal investigator, indicated substantial progress in developing a measuring device in a progress report entitled "Fouling and Corrosion Studies in OTEC-Related Heat Exchanger Tubes;" this report was forwarded on February 20, 1976. (1) Subsequent efforts to place one of his devices in operation at Keahole Point, Island of Hawaii, were unsuccessful and deployment problems resulted in the need to prepare another device for this mission. Since the project appeared to offer the potential for acquiring useful biofouling and corrosion data in the near future an additional sum of $\$ 191,217$ effective May 15, 1976 was provided to continue work for 9 months on this project. Discovery of a defective submarine cable in June led to a further delay in gathering biofouling and corrosion data and a temporary change in plans for deploying the measuring device. An anchored vessel, the research vessel Noi'i of the University of Hawai $i$, was used to hold the measuring devices and associated equipment; operation started on July 13, 1976 with one aluminum tube. On August 19, 1976 another device with an aluminum tube was placed in operation. These two units remained in operation until September 26, 1976 when the approach of a typhoon caused the Noi'i to lift anchor and proceed to the shelter of a harbor on the Kona Coast. The data acquired from the operation of the biofouling measurement devices on the Noi'i and earlier testing at Makapuu Point, Oahu, are briefly discussed in a later subsection of this report. 


\section{Development of Low Energy Surfaces}

In 1975 a project was funded at Allied Chemical entitled "The Prevention of Biofouling on Heat Converters" for $\$ 47,250$. The research conducted by $P$. E. Jones was directed toward examining thin films with good heat transfer properties that would have a low surface energy. It was believed by the investigators that such surfaces might substantially reduce microfouling. No decision on follow-on work was made in FY-1976 pending a review and evaluation of the final report ${ }^{(2)}$ and progress on this project.

\section{Pit Initiation and Growth on Aluminum}

An exploratory study of the factors influencing pit initiation and growth on aluminum was funded by ERDA at the University of Delaware in June 1976. This research, under the direction of $\mathrm{Dr}$. Stephen Dexter, is focused on better defining the effects of copper and iron ions, and oxygen concentration on pitting. ERDA transferred technical monitoring responsibility for this $\$ 52,193$ contract to the Biofouling and Corrosion Project Activity Office in the summer of 1976.

\section{Aluminum-Ammonia-Sea Water Corrosion}

As part of an OTEC-sponsored project on heat transfer, the corrosion behavior of aluminum in ammonia contaminated by artificial seawater was investigated by Alcoa under a subcontract from CMU in FY-1976. Since cognizant responsibility for this entire project (entitled "Concurrent Studies of Enhanced Heat Transfer and Materials for Ocean Thermal Exchangers") rests with the Heat Exchange Project Activity Office, the Biofouling and Corrosion Project Activity Office was involved only in the onsite project review and in evaluating a proposal for follow-on work. Progress on defining the aluminum behavior in the subject medium was given in an appendix to the CMU report dated February 9, 1976 entitled "Concurrent Studies of Enhanced Heat Transfer and Materials for Ocean Thermal Exchangers."(3) The work emphasized corrosion at low ammonia concentrations. Although some data are given for 70 and 100\% ammonia, further work is needed in the $90 \%+$ region to define the nature of any potential corrosion problems that may be expected under normal operating conditions. 
Unsolicited Project Proposals

Eighteen unsolicited project concepts or proposals were received by the Biofouling and Corrosion Project Activity Office in FY-1976 and the Transition Quarter. Ten of these were examined for technical merit in the reporting period; the remainder were carried over into FY-1977 when another review session is scheduled. Of the ten, one proposal from Sigma Research, Inc. of Richland, Washington entitled "Compatibility Studies for the System Water-Ammonia-Titanium as Related to Ocean Thermal Energy Conversion," was recommended to ERDA Headquarters for funding. A contract for $\$ 73,783$ was signed on September 30, 1976 to examine the stress corrosion cracking behavior of titanium in ammonia and seawater. Another task on this project is concerned with determining if galvanic corrosion of titanium in contact with mild steel in a working fluid environment of ammonia and seawater is a potential OTEC problem.

\section{Newly Developed Projects}

The Biofouling and Corrosion Project Activity Office held a meeting in Seattle, Washington in March 1976 to develop a list of projects needed for a comprehensive program to define, control and/or alleviate OTEC biofouling and corrosion problems. Consultants to the project activity office played a significant roll in this endeavor as well as certain other individuals from other Project Activity Offices and el sewhere on the OTEC Program. A list of 15 projects resulted from this meeting and, of this number, five were to be funded with FY-1976 monies. The information that follows briefly identifies these projects and the contractor who will conduct the project.

- A study to Evaluate Existing Data on Primary Organic Film--The Naval Post Graduate School, Monterey, California.

This $\$ 9,000$ project will establish what is known of primary film formation, so this information can guide the development of other projects that may be needed to define, control and alleviate OTEC biofouling problems. This information will also provide a background for contractors who may be working in this field. 
- A Critical Review of Design Factors Influencing Biofouling and Corrosion of (OTEC) System Surfaces--The Civil Engineering Laboratory, Naval Facilities Engineering Command, Port Hueneme, California. Orientation, shape, geometry and layout may have an appreciable effect on both biofouling and corrosion. This project was funded for $\$ 25,000$ to examine existing information to determine what is known about the effect of these variables on biofouling and corrosion under potential OTEC conditions. Areas will be identified that might define potentially attractive design methods for reducing biofouling and corrosion problems. The scope of work was expanded in September 1976 to include the examination of materials being recovered from the ocean off of St. Croix. An additional $\$ 10,000$ was added to the contract to cover this new work.

- Investigation of OTEC Heat Exchanger Cleaning Methods--Hydronautics, Inc., Laurel, Maryland.

This $\$ 64,700$ project will establish the state-of-the-art in cleaning OTEC heat exchangers. This project is to be completed by April 1977 and should provide a background on this technology for OTEC efforts in heat transfer as well as biofouling and corrosion.

- Catalog Information on the Performance of Aluminum in Seawater-Alcoa, Pittsburgh, Pennsylvania.

This $\$ 34,975$ project will establish what is known about aluminum corrosion in seawater for those alloys that may be used in an OTEC system. Knowledge of this information is needed to help guide future project development activities.

- A Study of Methods for the Prevention and Control of Fouling on Floating Platforms and Heat Exchange Surfaces Exposed to Seawater for OTEC Power Plants--David W. Taylor Naval Ship Research and Development Center, Annapolis, Maryland.

This $\$ 75,000$ project will develop information on cleaning and fouling control techniques that might be used for the OTEC platform. The project is expected to take 12 months to survey existing information and make a techno-economic assessment of the cleaning versus fouling prevention techniques. 
TECHNICAL ACCOMPLISHMENTS

Only three projects had been underway for a sufficient length of time in FY-1976 and the Transition Quarter to have generated an appreciable amount of information. These three projects were those that were identified in an earlier subsection entitled "Follow-On Projects". More detailed technical information follows.

Development and Use of a Biofouling and Corrosion Measuring Device

The Carnegie-Mellon University and its subcontractor (the University of Hawaii) have an ongoing project to develop and proof-test a device to measure biofouling and corrosion. Of particular interest are the thin proteinous and bacterial films that are routinely found on materials exposed to seawater. A 10-mil thick film of these organic materials and/or corrosion products is expected to reduce heat transfer in OTEC heat exchangers by $50 \%$ or more. To illustrate the difference in size and physical characteristics, consider classical barnacle fouling to be an order of magnitude greater than the fouling problem that is believed to be controlling the viability of the OTEC concept. If barnacles were to be present on the heat transfer surface the system would be well beyond economic operation.

Fetkovich and his coworkers at CMU have developed a device to measure the effects of the very thin films that are expected to be the controlling variable in the operating efficiency of OTEC heat exchangers. Their approach is based on measurements of the heat transfer coefficient, $h$, of the laminer fluid layer and the extent of biofouling (corrosion or scaling) on the seawater side of a heat transfer surface. Fetkovich derives the theoretical equation: $(1,4,5)$

$$
T(t)=T_{0} e^{-t / \tau}
$$

where

$$
\tau=\frac{C}{\pi \mathrm{DL} h}
$$

Equation (2) represents the time constant for the heat contained in a short, thick walled, test section attached to a standard heat transfer 
tube. The heat will then be transferred to seawater that is flowing in the tube. The basic assumptions in deriving Equation (1) are that the thermal conductivity of the tube test section is infinite and that heat flow is zero other than through the test surface. Fetkovich has developed a computer program which allows for the corrections that will obtain a real model capable of measuring $h$ to a precision of better than $1 \%$.

The basic heat exchanger apparatus is shown in Figure 2 and consists of a copper cylinder press fitted to a standard heat exchanger tube. Thermopiles are used for measuring temperature differences between the water and the copper block in the test section. A microme heater is used to heat the copper block to approximately $2^{\circ} \mathrm{C}$ above the temperature of the water flowing in the system. Pumps, control valves, etc., are all available for operating at water velocities from 2 to $8 \mathrm{ft} / \mathrm{sec}$. The whole apparatus is encased in a PVC envelope for undersea operation. Data can be transmitted to shore by a multiplexing system and cable.

Since the voltage output of the thermopile system is proportional to the temperature difference Equation (1) becomes

$$
V_{T C}(t)=V_{T C}(0) e^{-t / \tau}
$$

and direct measurement of the time constant and $h$ is possible. The heat transfer coefficient for water flowing in bare tubes varies as follows:

$$
h=\frac{160\left(1+0.012 T_{f}\right)}{D^{0.2}} v^{0.8}
$$

and a plot of $\frac{1}{h}$ versus $v^{0.8}$ should result in a straight 1 ine. Thus, measurements taken at successive times and different velocities measure the rate of biofouling.

$$
\begin{aligned}
& \text { Nomenclature } \\
& T()=\text { Temperature } \quad h=F i l m \text { heat transfer coefficient } \\
& \mathrm{t}=\text { Time } \\
& D=\text { Inside tube diameter } \\
& \mathrm{C}=\text { Heat capacity of metal test } \\
& \text { section } \\
& L=\text { Length of heated section } \\
& \operatorname{VTC}()=\text { Thermopile voltage } \\
& V=\text { Velocity of the fluid flowing } \\
& \text { in the tube. } \\
& T_{f}=F i l m \text { temperature }
\end{aligned}
$$




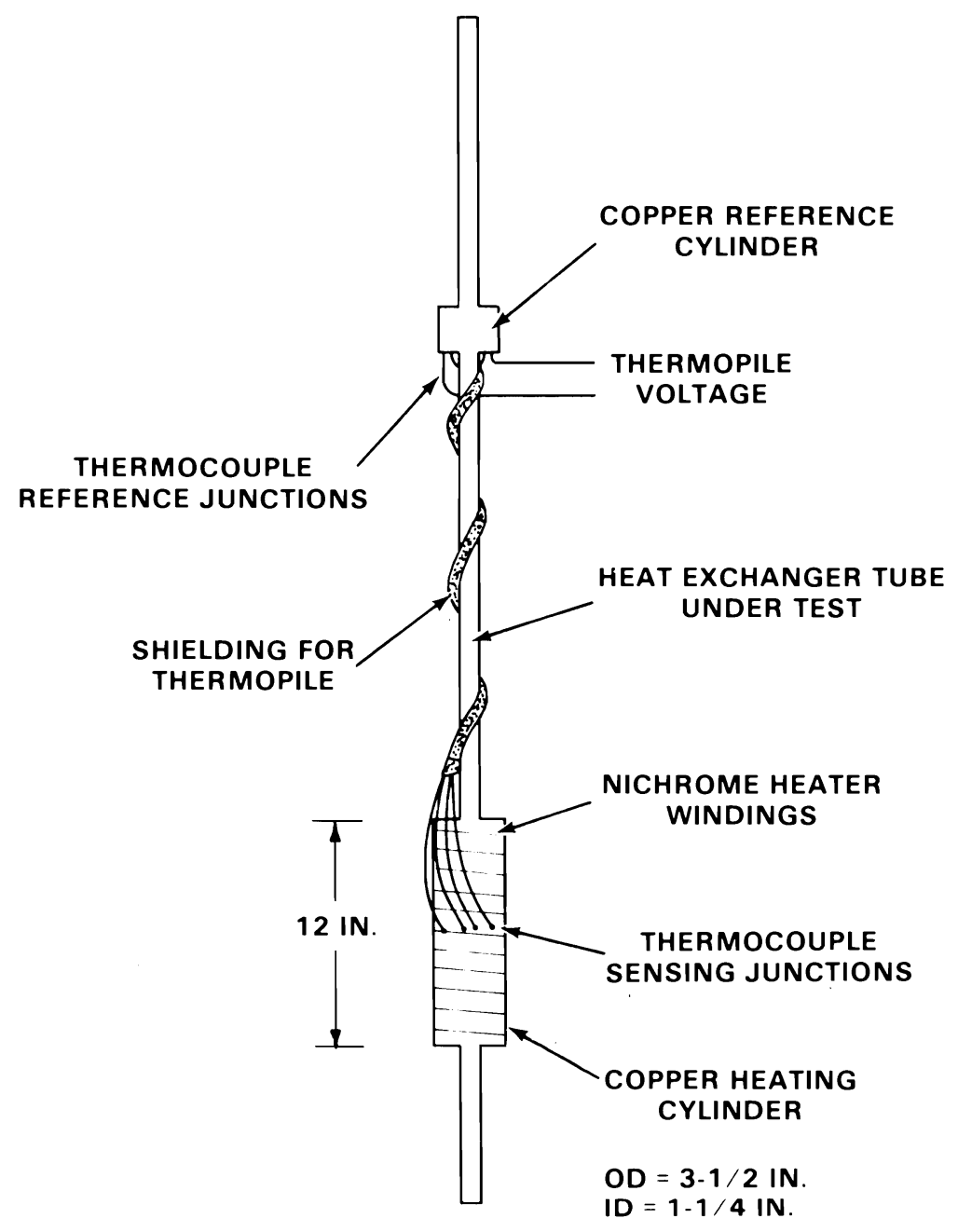

FIGURE 2. Tube with Instrumentation (1)

A typical voltage decay curve is shown in Figure 3. Data for preliminary tests off Makapuu Point, Hawai $i$, is shown in Figure 4 where $h$ is measured as a function of water velocity using a 90-10 Cu/Ni tube. The straight line represents data for a clean tube. A preliminary fouling factor of $13 \pm 2 \times 10^{3} \mathrm{Btu} / \mathrm{hr} /{ }^{\circ} \mathrm{F}-\mathrm{ft}^{2}$ was calculated from these data. The test period was from March 7, 1976 through April 18, 1976. By repeating the test at weekly or monthly intervals, the change in the fouling factor with time can be determined. 


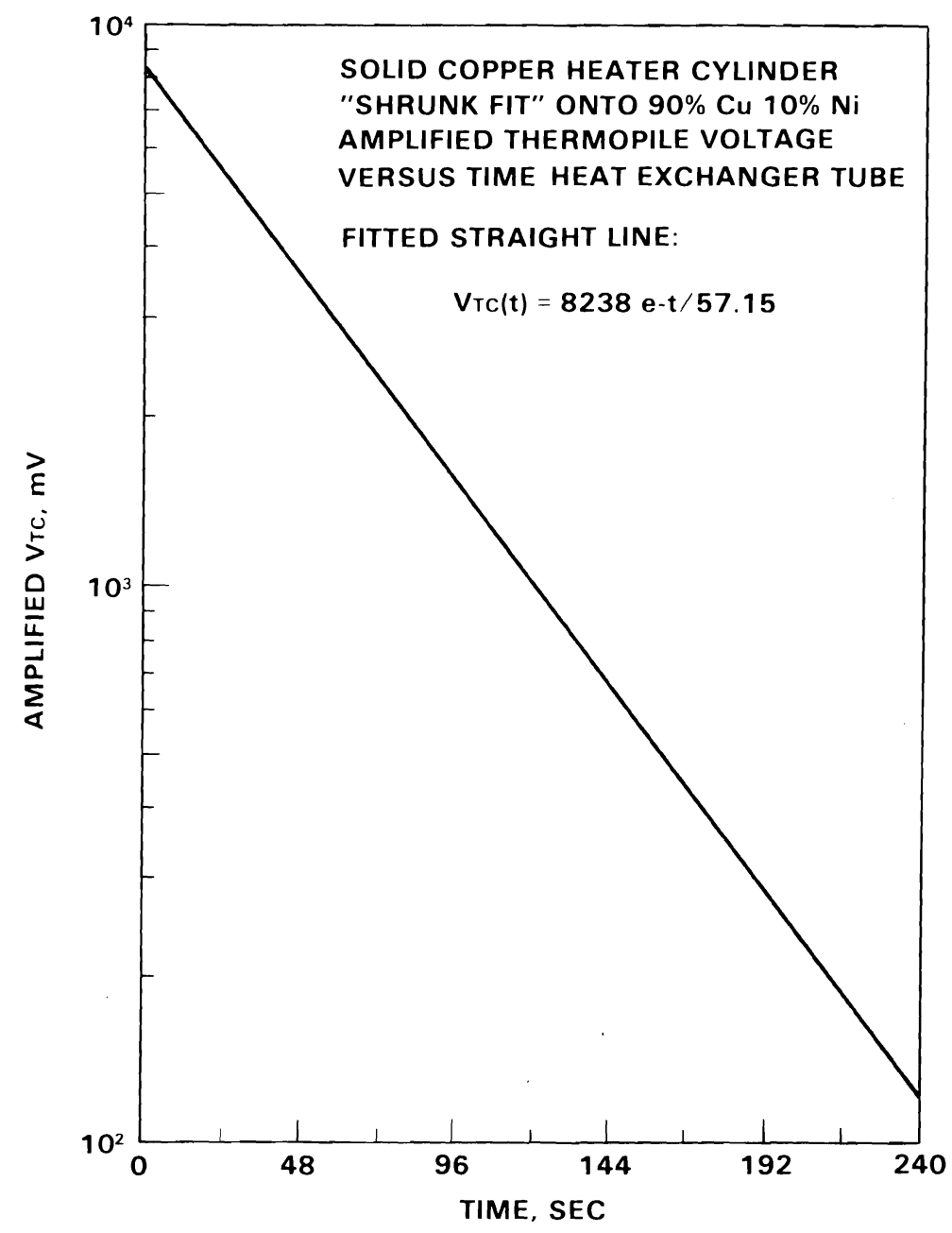

FIGURE 3. Decay of Temperature (Thermopile Voltage) with Time ${ }^{(4)}$

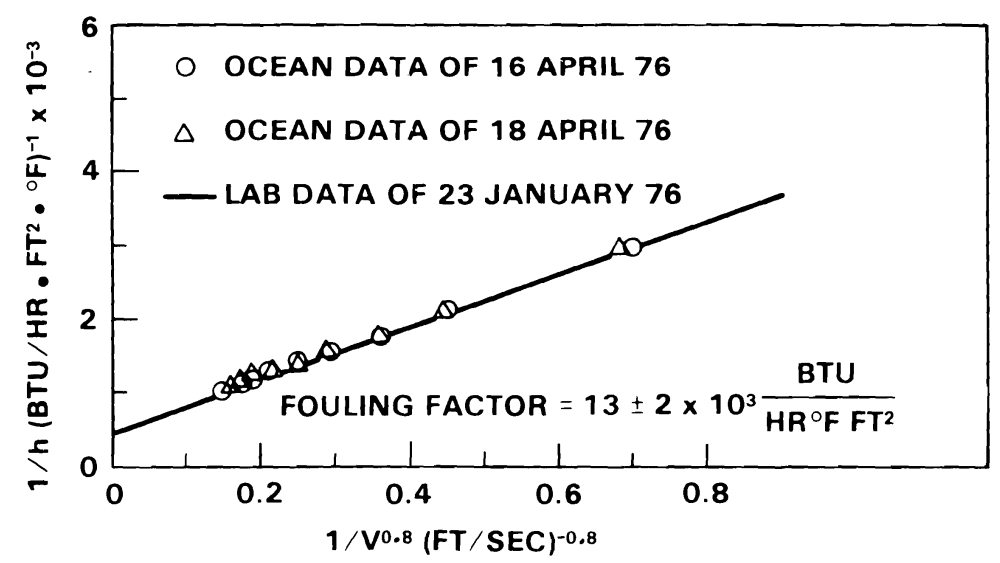

FIGURE 4. Variation of $1 / \mathrm{h}$ with $1 / \mathrm{v}^{0.8^{(5)}}$ 
Additional data on the character of the film will be obtained by sectioning the tube after completion of the at-sea test program. The specific character of the various organisms on the surface will be determined along with the extent and type of corrosion experienced on the heat transfer surface.

One CMU device was deployed off Keahole Point, Island of Hawaii on July 13, 1976 and a second was deployed August 19, 1976. On September 26, 1976 these tests were terminated prematurely because of a typhoon warning and the data are therefore incomplete. Aluminum tubes (6061-T6 Alloy) were used in both experiments. The velocity of the seawater flowing in the tubes was 3 and $6 \mathrm{ft} / \mathrm{sec}$, respectively. The data which were obtained are found in Tables 1 and 2, and the change in thermal resistance of the film is found in Figure 5. Both tubes were carefully removed from the water, quickly examined and carefully stored using procedures specified by marine biologists at the University of Hawaii and corrosion people at CMU. The preliminary examination revealed a green slime-like layer on one of the tubes and a green turning to brown layer on the other tube. The tubes were sectioned after arrival in port and are now being examined at the University of Hawai $i$ and CMU to further define the biofouling and corrosion which is present on the tubes after their removal from the ocean. The inner surface of each tube was cleaned free of grease and dirt by washing with a cloth soaked with acetone prior to the ocean test. No other cleaning procedure or surface preparation was used.

Unfortunately, these data are very preliminary and incomplete, and evaluations of the fouling on the tube surface are continuing. It would be dangerous, therefore, to draw specific conclusions as to the extent and characteristics of the biofouling or corrosion layer without additional and longer term data. It is quite apparent, however, that in the ocean at the Keahole test site biofouling and perhaps corrosion does have an impact on heat transfer through aluminum tubes. 
TABLE 1. Nominal Flow Velocity: $3 \mathrm{ft} / \mathrm{sec}$

Material: A1 6061-T6 (Tube No. 1) (a)

\begin{tabular}{|c|c|c|c|c|c|}
\hline Date & $\left(\begin{array}{c}\langle h> \\
\left(\frac{B t u}{h r-f t^{2}-{ }^{\circ} F}\right.\end{array}\right)$ & $\begin{array}{c}\quad\left(\frac{\mathrm{hr}-\mathrm{ft} \mathrm{t}^{2}-{ }^{\circ} \mathrm{F}}{\mathrm{Btu}}\right) \times 10^{5} \\
\end{array}$ & $\begin{array}{c}\Delta\left\langle\left(\frac{l}{h}\right)>=R_{f}\right. \\
\left(\frac{h r-f t^{2}-{ }^{\circ} F}{B t u}\right) \times 10^{5}\end{array}$ & $\begin{array}{c}\frac{d}{d t}\left(R_{f}\right) \\
\left(\frac{h r-f t^{2}-{ }^{\circ} F}{\text { Btu week }}\right) \times 10^{5}\end{array}$ & $\begin{array}{c}\mathrm{t}_{\mathrm{f}} \\
\left(\mathrm{mi} \mathrm{I}_{\mathrm{s}}\right) \\
\end{array}$ \\
\hline July $13-17,1976$ & $551.6+7.0$ & $181.3 \pm 2.3$ & 0.0 & $\ldots$ & 0.0 \\
\hline Aug. 10, 1976 & $535.4 \pm 6.6$ & $186.8 \pm 2.3$ & $5.5+3.3$ & $1.48 \pm 8.89$ & $0.23 \pm 0.14$ \\
\hline Aug. 31, 1976 & $486.8 \pm 3.8$ & $205.4 \pm 1.6$ & $24.1 \pm 2.8$ & $6.20 \pm 1.44$ & $1.01 \pm 0.12$ \\
\hline Sept. 15, 1976 & $424.7 \pm 2.9$ & $235.5+1.6$ & $54.2 \pm 2.8$ & $14.00 \pm 1.84$ & $2.27 \pm 0.12$ \\
\hline Sept. 22, 1976 & $386.5+3.3$ & $258.7 \div 2.2$ & $77.4 \pm 3.2$ & $23.2 \pm 4.3$ & $3.25 \pm 0.13$ \\
\hline
\end{tabular}

TABLE 2. Nominal Flow Velocity: $6 \mathrm{ft} / \mathrm{sec}$

Material: A1 6061-T6 (Tube No. 2)(a)

\begin{tabular}{|c|c|c|c|c|c|c|c|c|c|c|}
\hline & $\left(\begin{array}{r}<h \\
B t \\
h r-f t\end{array}\right.$ & $\left.\frac{u}{2-{ }^{\circ} F}\right)$ & $\left(\frac{h r-f t^{2}{ }^{\circ} \mathrm{F}}{\mathrm{Btu}}\right)$ & $\times 10^{5}$ & $\begin{array}{r}\Delta<\left(\frac{l}{h}\right)> \\
\left(\frac{h r-f t^{2}-{ }^{\circ} p}{B t u}\right.\end{array}$ & $=10^{5}$ & $\begin{array}{r}\frac{d}{d t}( \\
\frac{h r-f t^{2}-\circ}{\text { Btu week }}\end{array}$ & F) $\times 10^{5}$ & \multirow{2}{*}{\multicolumn{2}{|c|}{$\frac{t_{f}}{\left(m i l_{s}\right)}$}} \\
\hline , 1976 & 922.5 & 25.5 & 108.4 & 3.0 & \multicolumn{2}{|c|}{0.0} & \multicolumn{2}{|c|}{---} & & \\
\hline 1976 & 918.3 & 1.0 & 108.9 & 1.3 & 0.5 & 3.3 & 0.32 & 2.1 & 0.021 & 0.14 \\
\hline 13, 1976 & 825.1 & 9.5 & 121.2 & 1.4 & 12.8 & 3.3 & 6.15 & 2.33 & 0.54 & 0.14 \\
\hline 18,1976 & 811.7 & 21.1 & 123.2 & 3.2 & 14.8 & 4.4 & 2.78 & 7.6 & 0.62 & 0.18 \\
\hline , 1976 & 730.5 & 12.8 & 136.9 & 2.4 & 28.5 & 3.8 & 12.02 & 5.10 & 1.20 & 0.16 \\
\hline
\end{tabular}

(a) J. G. Fetkovich, Department of Physics, Carnegie Mellon University, Schenley Park, Pittsburgh, Pennsylvania 


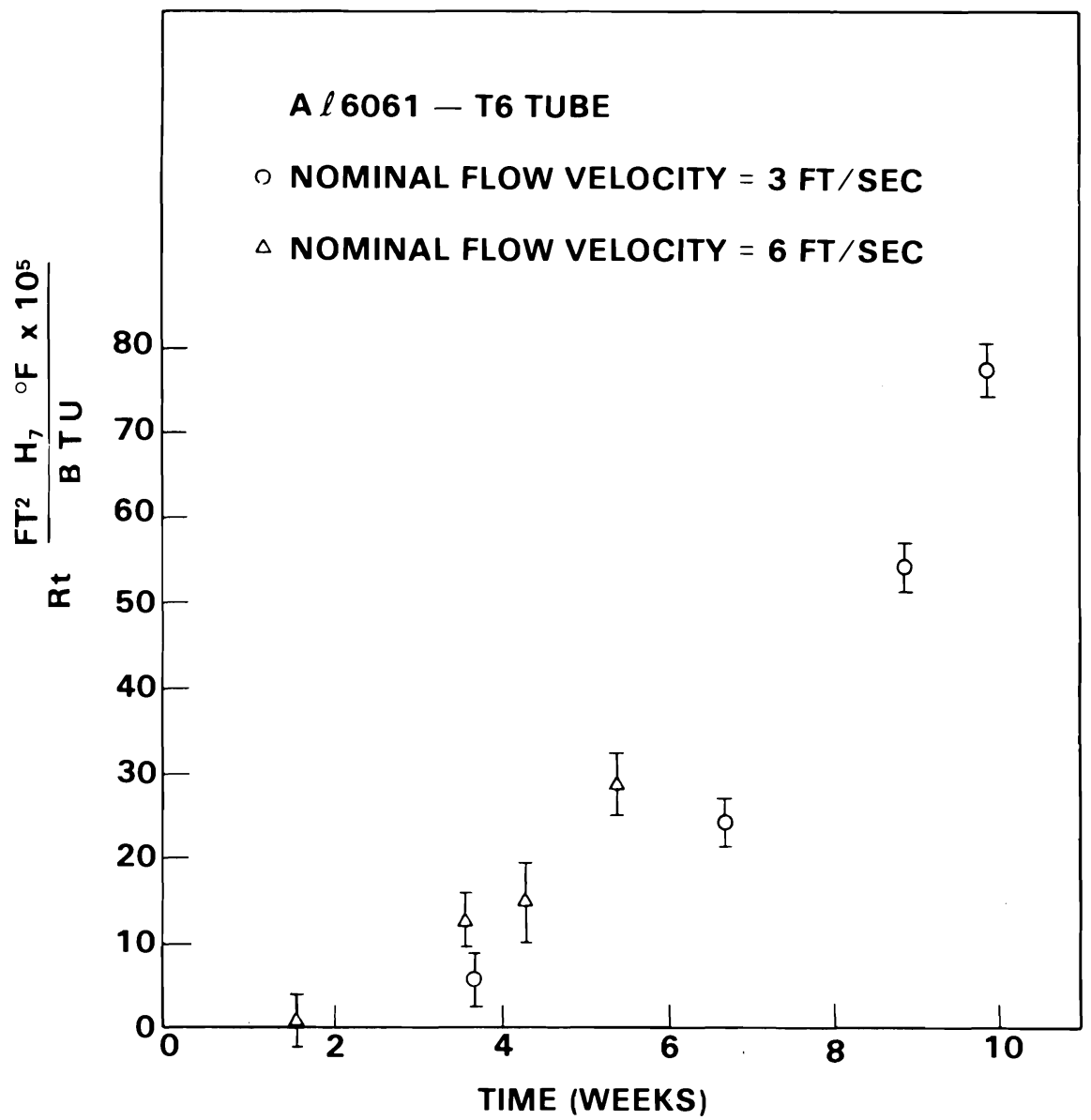

FIGURE 5. Thermal Resistance Due to Biofouling and Corrosion Product (a)

\section{Aluminum-Ammonia-Seawater Corrosion}

Recently, Alcoa completed a preliminary study of the behavior of three aluminum alloys in ammonia-seawater mixtures. (3) The stimulus for their study comes from the baseline design conditions chosen for OTEC power plants. The leading candidate for a working fluid to drive the turbines in the power cycle is ammonia. One of the materials that is being considered for evaporator and condenser tubing is aluminum. If aluminum alloys which are less costly than other materials considered for tubing are to be used, they must be compatible with the working fluids under conditions that would be encountered in routine and off-standard OTEC operations.

(a) J. G. Fetkovich, Department of Physics, Carnegie Mellon University, Schenley Park, Pittsburgh, Pennsylvania 
During the Alcoa study, Bonewitz examined aluminum alloys 1100, 3003, 5052 and 6063. Emphasis was placed on defining the effects of surface areato-volume and ammonia concentrations which are key variables in establishing the compatibility of aluminum alloys with conditions that may be encountered in OTEC operation.

Initial surface area-to-volume tests were made with coupons of aluminum alloy 1100. Only a slight surface area to volume effect was found in 5 and 10\% ammonia solutions in artificial seawater. At 5,10 and 30\% ammonia with the other alloys or with two or more alloys together, little if any effect was noted. From these lower concentration tests Bonewitz concluded that surface area-to-volume was not likely to be a major corrosion variable for aluminum in ammonia contaminated with seawater. These tests also established that there was little discernible difference in behavior to this effect between the four alloys under investigation.

The other major area of Bonewitz's study was directed toward an examination of ammonia concentration and time on 1100, 3003, 5052 and 6063 alloys. The information given in Figure 6 for alloy 1100 in various concentrations of ammonia in seawater is typical of the results the investigator found for all four alloys. The data for demineralized water has been added to give additional perspective to the study. In lower concentrations there was a higher corrosion loss at 15 days than was found in the concentration range of 30 to $70 \%$ ammonia. An increase attack is shown in the 70 to $100 \%$ concentration range. Although the exact form of the curve in this region was not established, it should be. In a11 likelihood, most operation of OTEC power plants will be with only small amounts of seawater contamination, probably with $5 \%$ or less. By comparing the curves for behavior in artificial seawater with demineralized water, it can be seen that the latter is more corrosive.

With other experiments, Bonewitz found that corrosion rates were high, initially ( 12 to $19 \mathrm{mil} / \mathrm{yr}$ ), but decreased for 5 and $10 \%$ ammonia to 3 and $6 \mathrm{mil} / \mathrm{yr}$ after a week. Apparently, a passive film had formed or was forming to reduce the severity of attack. The data shown in Table 3 were taken from Bonewitz's report ${ }^{(3)}$ and identify the rate information as well as the type of attack he found by visual and metallographic means. 


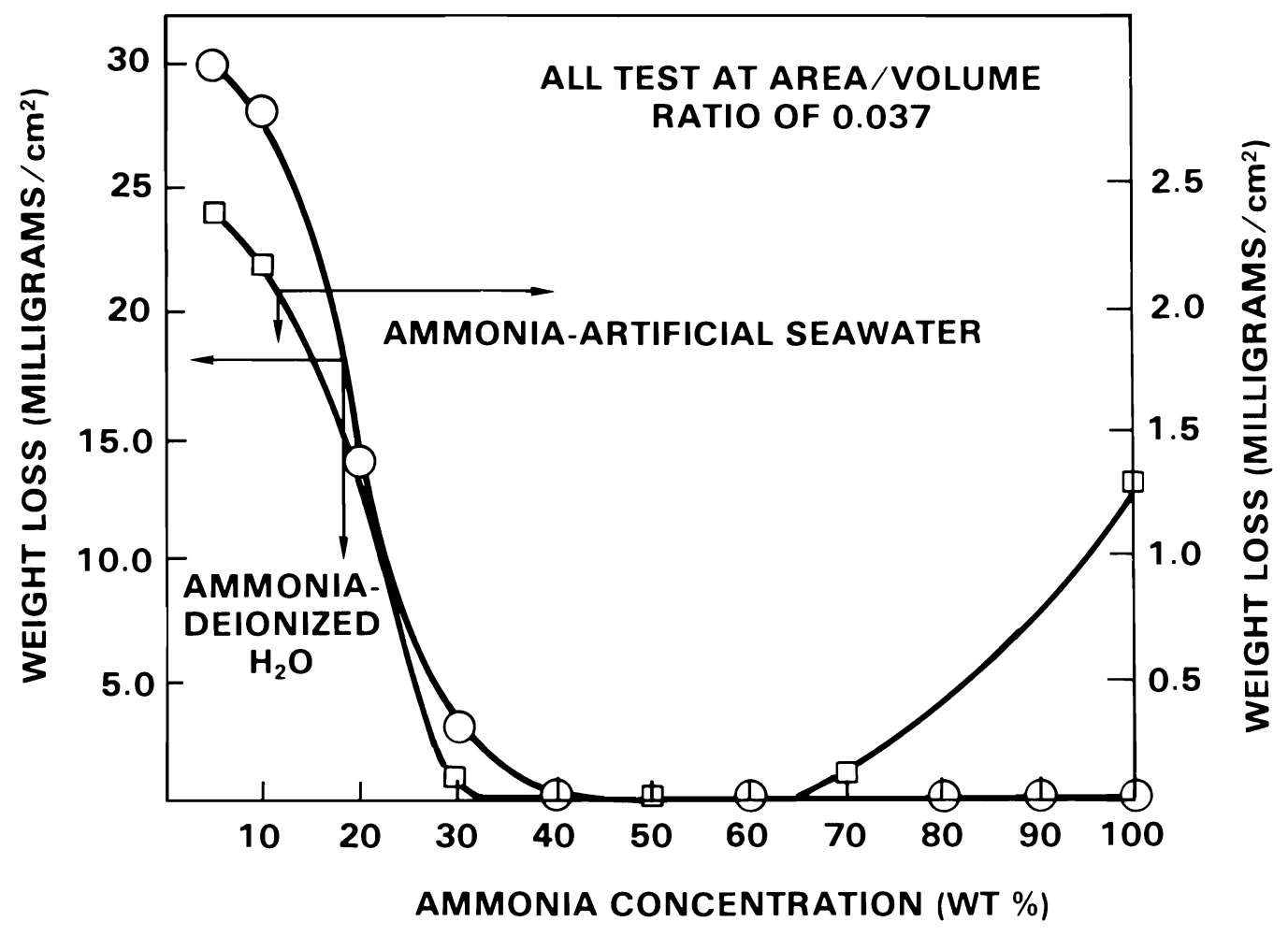

FIGURE 6. Corrosion of 1100 Alloy in Ammonia - Deionized/Seawater Solutions

TABLE 3. Rate and Type of Attack Information(3)

\begin{tabular}{c}
$\begin{array}{c}\text { Ammonia } \\
\text { Concentration, } \\
\text { wt\% }\end{array}$ \\
\hline 5 \\
10 \\
30 \\
50 \\
70 \\
90 \\
100
\end{tabular}

\begin{tabular}{c}
$\begin{array}{c}\text { Corrosion Rate, } \\
\text { mils/yr(b) }\end{array}$ \\
\hline 3 \\
6 \\
0.1 \\
0.3 \\
0.06 \\
0.4 \\
0
\end{tabular}

(a) Calculated from weight loss

(b) $1 \mathrm{mil} / \mathrm{yr}=0.001 \mathrm{in} .=0.0004 \mathrm{~cm}$ 
It should be understood that the research conducted by Alcoa on aluminum corrosion was an initial step of many that are required before the behavior of this material under expected OTEC conditions can be established. The results of the Alcoa effort and others that are expected to follow should be of interest not only to those who are involved in OTEC work, but to all who are concerned with the performance of materials in marine environments.

Development of Low Energy Surfaces

The report on a project completed before it was assigned to the Biofouling and Corrosion Project Activity Office is under review. A summary of results will be reported in FY-1977. 


\section{PROJECT MANAGEMENT}

The mission of the Biofouling and Corrosion Project Activity Office is to assist ERDA with a supportive effort on planning, developing and monitoring projects to define, control and alleviate OTEC biofouling and corrosion problems. The administrative and operational aspects of this supportive effort are the subjects of this portion of the annual report. They will be discussed under subdivisions concerned with: 1) establishing the Project Activity Office, 2) personnel acquisition, 3) project development, 4) project evaluation and control procedures, 5) budgets and costs, and 6) technology transfer.

\section{ESTABLISHING PROJECT ACTIVITY OFFICE}

Pacific Northwest Laboratory efforts in establishing a project activity office to undertake work on OTEC biofouling and corrosion problems were in response to various written and oral directives from ERDA. PNL was asked to assist in planning and developing projects to define, control and alleviate biofouling. This request came in a December 1975 letter from Dr. H. H. Marvin, Director, Division of Solar Energy, ERDA, to A. G. Fremling, Manager, Richland Operations Office. This letter was subsequently issued as a program letter. Later, the scope of PNL's work was expanded to include corrosion as well as biofouling, and that project monitoring was to be an integral part of the effort to ensure that specific project objectives were achieved in a timely and cost effective manner.

The PNL response to these requests involved several activities. Effective January 1, 1976, Lyle D. Perrigo (Chemical Technology Department, which is one of 12 research departments at PNL) became Manager of the biofouling activities and later of the corrosion activities required by ERDA. Figures 7 and 8 show how the Biofouling and Corrosion Project fits into the OTEC Program conducted by ERDA, and the OTEC Program's position in the Chemical Technology Department, PNL. One of the first tasks of this office 


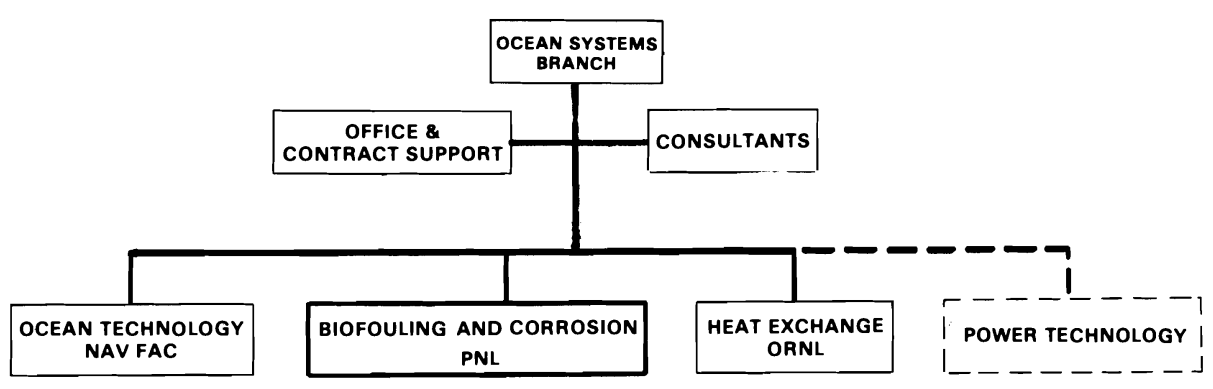

FIGURE 7. OTEC Organization

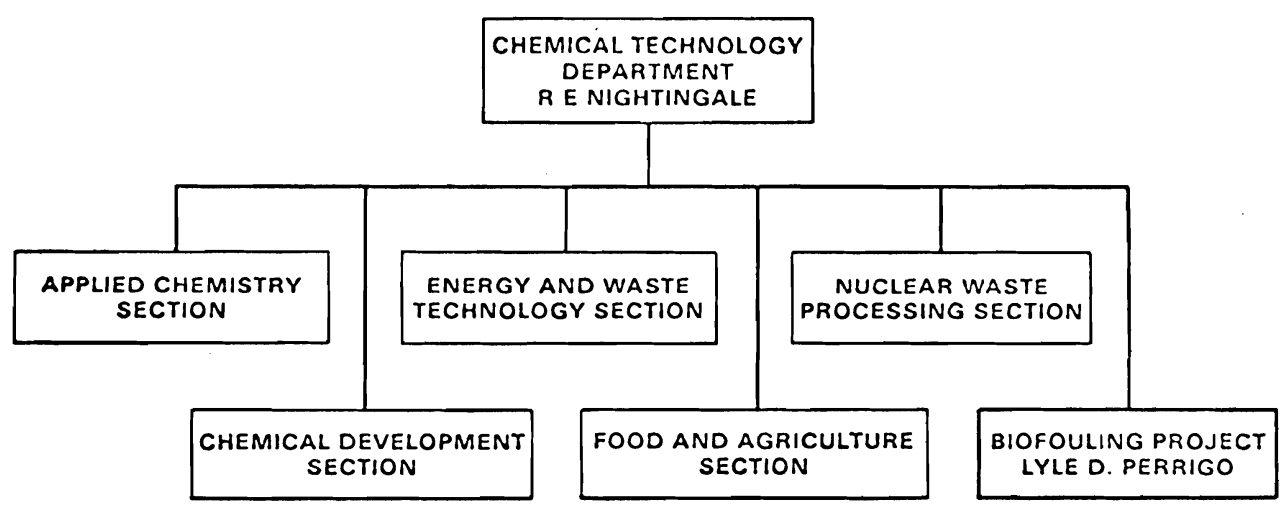

FIGURE 8. Department Organization 
was to establish communications and liaison with these various other entities involved in the OTEC Program. Figure 9 shows the major elements involved in routine communications concerning the Biofouling and Corrosion Project Activity Office.

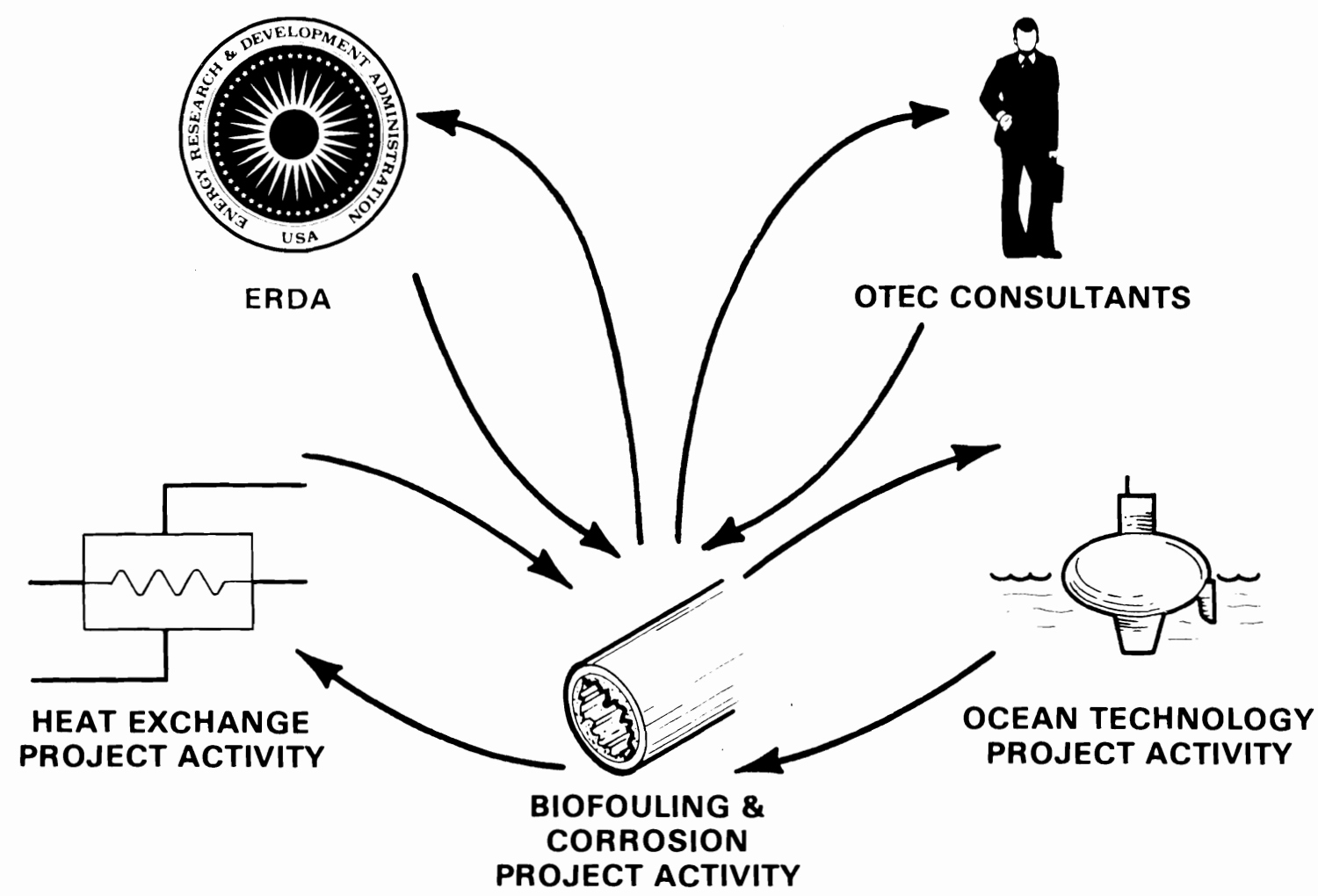

FIGURE 9. OTEC Communications

The second major undertaking in establishing the Project Activity Office was to define budgetary needs and secure needed funds by Schedule 189s which were prepared for FY-1976 and the Transition Period as well as FY-1977. In an Apri1 1976 letter, Dr. H. H. Marvin authorized an additional \$600,000 for the Biofouling and Corrosion Project Activity Office bringing the FY-1976 total to $\$ 650,000$. Subsequently an obligation authority of $\$ 822,000$ was established for the Transition Quarter. These funds provided the means for funding projects and operating the Project Activity Office. Additional information on budgets will be provided in another subsection. 
The project activity office was organized to utilize two general categories of people: 1) staff members at PNL, and 2) consultants. It was believed that a multidisciplinary effort with major responsiblities for strong project management would best be served by such an arrangement. Figures 10 and 11 iliustrate this two-category arrangement and some of the joint functions undertaken by the two groups. In addition, the PNL staff of the Biofouling and Corrosion Project Activity Office has other functions concerned with administration, budgeting, communications, coordination, procurement and technology transfer. More detailed information on these work functions are presented in other subsections concerned with project management.

Another task was to develop a management plan which was presented orally to the Branch Chief of OTEC and various consultants in February 1976. Subsequently, PNL was authorized to proceed with the preparation of a program master plan. A comment draft of that master plan was nearing completion at the end of the Transition Quarter.

A project status report was delivered to the Ocean Systems Branch, ERDA in Washington, D.C. on September 9, 1976. A presentation was also made before the Marine Board, National Academy of Engineering, in Los Angeles, California, on August 23, 1976.

\section{PERSONNEL ACQUISITION}

One of the initial tasks for the Biofouling and Corrosion Project Activity office was to acquire knowledgeable and interested personnel within and outside of Battelle to assist the manager of this operation in carrying out the mission of the project activity office. George A. Jensen and Donna B. Cash at PNL were acquired on a part-time bas is in January and February to provide technical and administrative support. Beginning in February a number of internal and external consultants were retained to provide scientific and technical support. These individuals who are now serving in this capacity are listed on Page 29 as well as a brief statement of their specialties. 


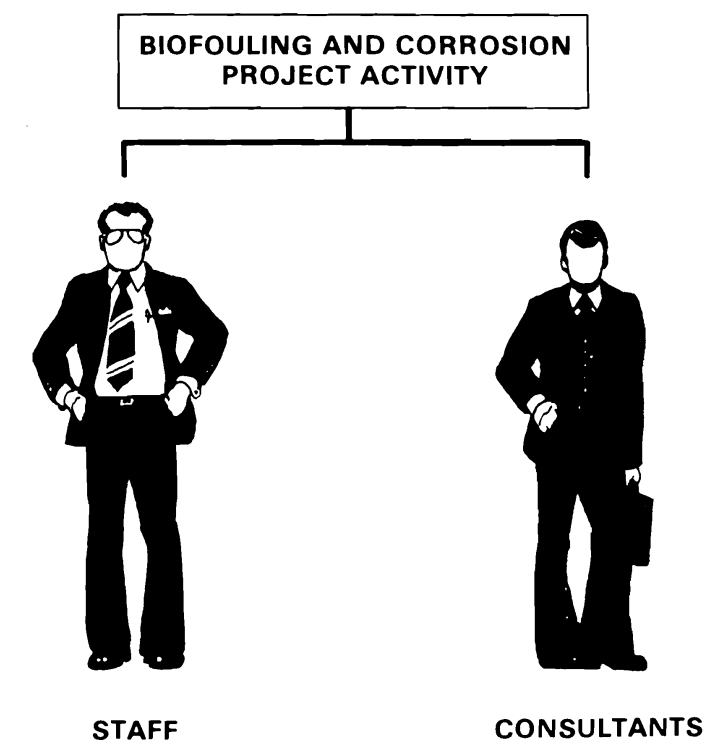

FIGURE 10. Biofouling and Corrosion Project Organization

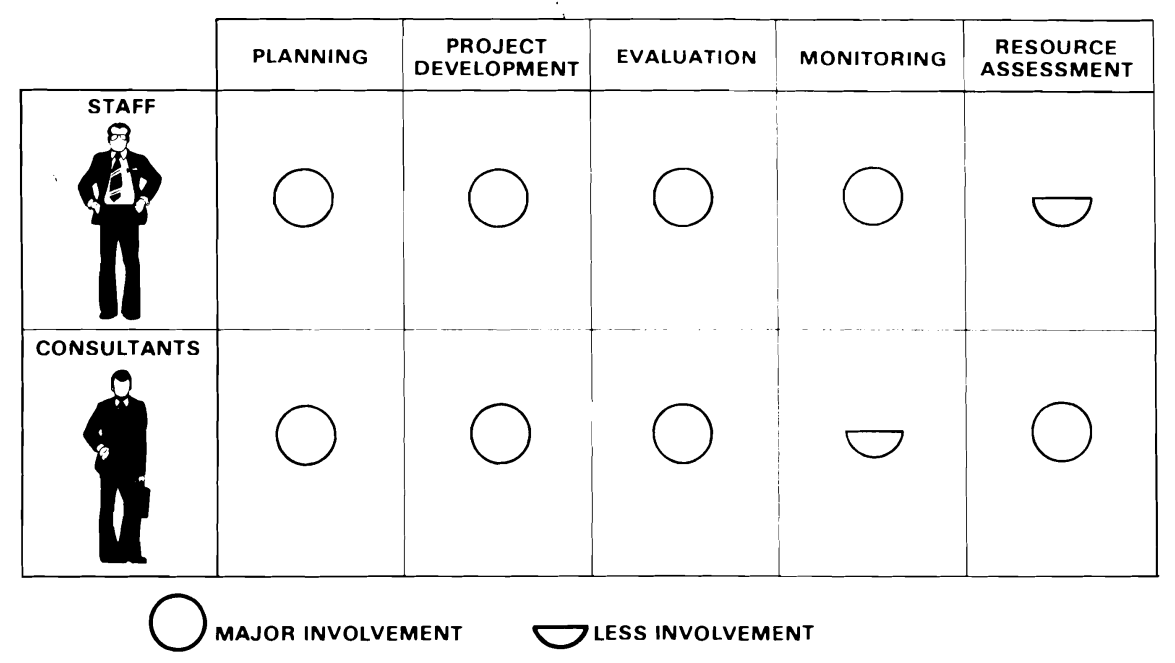

FIGURE 11. Joint Functions 
- Walter K. Boyd, Manager, Corrosion and Electrochemistry Section, Battelle Columbus Laboratories, Columbus, Ohio; marine corrosion.

- Dr. Richard W. Drisko, Senior Project Scientist, Materials Science Division, Civil Engineering Laboratory, Port Hueneme, California; marine corrosion and macrofouling.

- Dr. C. I. Gibson, Manager, Marine Research Laboratory, Battelle, Sequim, Washington; marine ecology.

- Dr. E. C. Haderlie, Professor of Oceanography, Naval Post Graduate School, Monterey, California; marine macro and microfouling.

- W. W. Laity, Systems Engineering Section, Pacific Northwest Laboratories; marine engineering and heat transfer.

- Dr. F. L. Laque, Consultant (former Executive Vice President, International Nickel Company), Verona, New Jersey; internationally recognized authority on marine corrosion.

At the present time the Project Activity Office is exploring the possibilities and advisability of acquiring an additional biofouling consultant.

\section{PROJECT DEVELOPMENT}

Three types of information are presented in this subsection on Project Development: 1) the procedures involved in starting new projects, 2) the definition and selection of projects, and 3 ) the identification of those in the procurement and development process at the present time. Additional information follows under the subheading concerned with these three categories.

\section{Project Development Procedures}

Several steps are involved in developing projects to define, control or alleviate OTEC biofouling and corrosion problems. Figure 12 shows the major steps in this process. The first one, idea generation, has been discussed previously but primarily as a subsidiary consideration to the end result of the process, the specific projects themselves. However, the 
Biofouling and Corrosion Project Activity Office has developed an idea generation method that involves: 1) using consultants to provide input on needed projects, and 2) selecting useful, unsolicited ideas provided by groups or organizations interested in OTEC. Basically, it is a process that uses both internal and external ideas to achieve objectives.

\begin{tabular}{|c|c|c|c|c|}
\hline $\begin{array}{c}\text { IDEA } \\
\text { GENERATION }\end{array}$ & \begin{tabular}{|c|} 
PROPOSAL \\
DEVELOPMENT
\end{tabular} & \begin{tabular}{|c|} 
REQUEST \\
DEVELOPMENT
\end{tabular} & $\begin{array}{l}\text { PROPOSAL } \\
\text { EVALUATION }\end{array}$ & $\begin{array}{c}\text { CONTRACT } \\
\text { AWARD }\end{array}$ \\
\hline
\end{tabular}

FIGURE 12. Project Development

The second major step in the proposal development process has several constituent elements (Figure 13). The first element is concerned with the preparation of a Statement of Work (SOW) which is generally done by one of the consultants to the Project Activity Office. Subsequently, it is reviewed by the Project Activity Office and another internal or external consultant. Following suitable revision it is forwarded to the OTEC Branch for comment. Concurrently, copies of the work statement are sent to certain consultants to OTEC or others involved in OTEC programs for what is terms in Figure 13 an external review. From comments received in this external review, the sow is then revised.

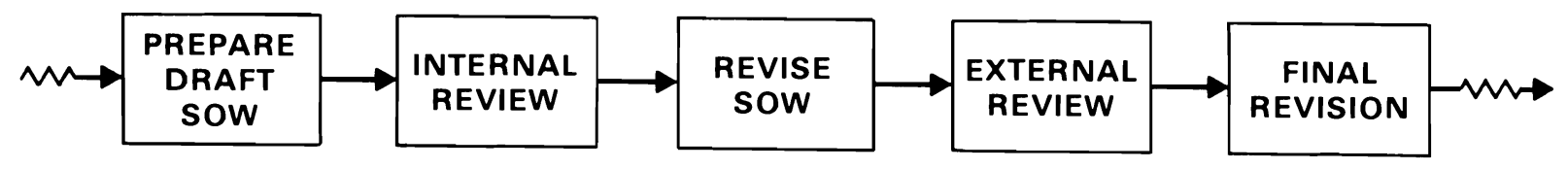

FIGURE 13. Proposal Development

The next major activity as shown in Figure 12 is concerned with the development of the request for proposals (RFP). The specific work elements involved in this activity are shown in Figure 14. All are handled by a 
Procurement Panel that is established under ERDA Procurement Procedures as established in "Interim ERDA Handbook-Source Evaluation and Selection," December 1975, and selected portions of the guides entitled "ERDA-PI 9-56" and "ERDA-PR 9-56." A new panel is set up for each procurement. These panels have consisted of the Manager of the OTEC Biofouling and Corrosion Project, the Project Engineer of this office, a procurement specialist, a financial specialist and a technical consultant to the Project Activity Office who may be called in if needed. The other steps in the process are essentially self explanatory from the elements given in Figure 14.

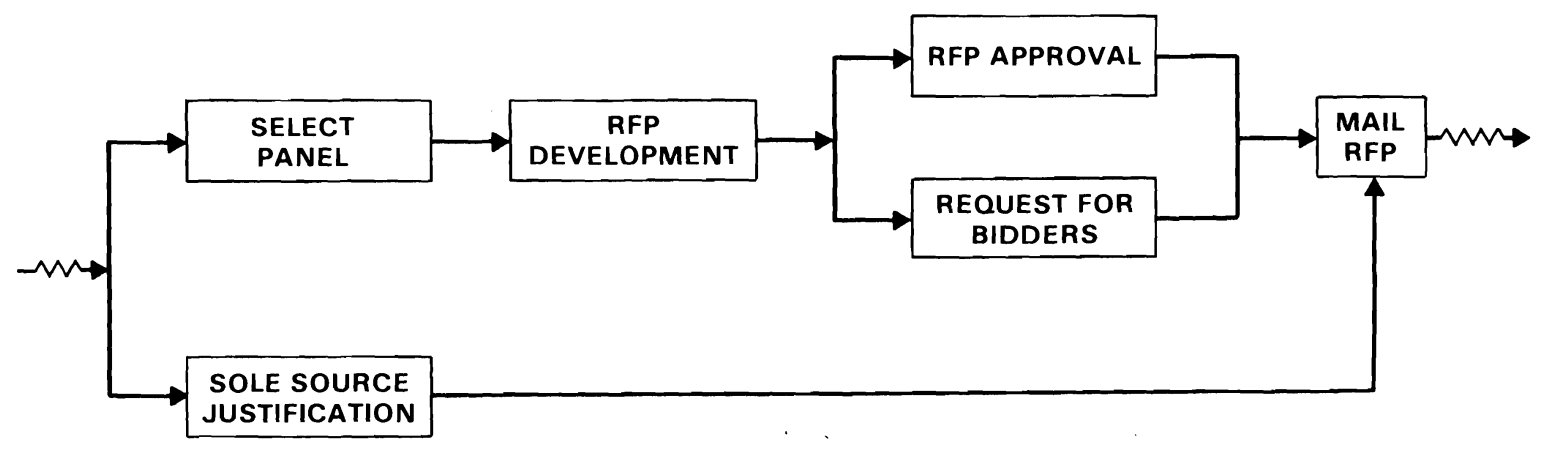

\section{FIGURE 14. Proposal Request Development}

\section{Definition and Selection}

Normally, the general area of scientific and technical endeavor undertaken by a Project Activity Office in support of an ERDA effort such as the Ocean Thermal Energy Conversion Program would be fully delineated in a program master plan. However, a different approach was needed due to the establishment of the Biofouling and Corrosion Project Activity Office at PNL on January 1, 1976 and the need to: 1) assume responsibility for ongoing projects, and 2) define and fund projects for contracting in FY-1976. Thus, a panel of scientific and technical experts reporting to the project activity office has helped to define near-term needs that could be translated in FY-1976 and Transition Quarter projects. Paralleling this nearterm effort was the development of a master plan for OTEC biofouling and 
corrosion that we anticipate will be completed in the first quarter of FY-1977. Once this master plan is approved, it will be a guide for future project definition and selection activities.

Important considerations in the definition and selection of FY-1976 projects were the need to: 1) fill technology gaps in the approach to solving anticipated OTEC biofouling and corrosion problems, and 2) commit available FY-1976 funds before the end of June 1976. As a result of the latter constraint, some of the projects identified at Seattle in March 1976 as high priority items became Transition Quarter or FY-1977 endeavors. The procurement process involved for certain types of contracts with estimated costs in excess of $\$ 100,000$ takes substantial periods of time. Table 4 lists the projects that were believed to be needed as of March 1976 .

TABLE 4. Projects Needed to Define, Prevent, and Alleviate OTEC Biofouling and Corrosion Problems

1. Development of a Biofouling Measurement Device

2. Development of a Device to Measure Velocity Effects on Biological Film Formation

3. Critical State-of-the-Art Study of Primary Film Formation on Cu-Ni, Aluminum, Titanium, Inconel-625, and Specific Plastic Materials

4. Critical Review of the Design Factors Influencing Biofouling and Corrosion of OTEC System Surfaces

5. Preparation of a Catalogue of Oxygen Concentration, $\mathrm{pH}$, Carbon Dioxide, Carbonates, and Temperature for Prime Oceanographic Sites

6. Critical State-of-the-Art Study on the Biofouling and Cleaning of Heat Transfer Surfaces in Existing Marine Systems

7. Catalogue Information on the Performance of Aluminum in Sea Water

8. Prepare a Catalogue of Shore Stations, Ships, Platforms, Buoys, etc., Where Meaningful Biofouling Work Might Be Done

9. Critical State-of-the-Art Study on Critical Cu Ion Concentration in Corrosion Products to Prevent Biofouling

10. Critical State-of-the-Art Study on the Economics Involved in Chemical/Mechanical Cleaning Versus Biofouling Prevention Techniques for Non-Heat Transfer Surfaces

11. Experimental Study of Galvanic Corrosion Effect in Concrete Rebar

12. Critical Review of the Literature on Polyester Behavior in the Ocean

13. Experimental Study of Behavior of Kelvar in the Ocean

14. Experimental Study of Effect of Batch Chlorination on Biofouling

15. Critical State-of-the-Art Study on the Nature and Extent of Corrosion in Steel Rebar and Stressed Tendons in Concrete 
The information in Table 5 shows other projects that were identified at a meeting of the Biofouling and Corrosion Project Activity Office at Monterey, California in June 1976 as being needed for a systematic attack on problems in the various areas of interest. It should be understood that these listings are constrained by the factors mentioned previously and the need to continuously reassess the need for certain types of work. For example, Items 8,12 , and 13 in Table 4 were dropped by the Project Activity Office since a sufficient amount of information was either believed to be currently available to provide the required information, or was found to be parts of ongoing research projects.

TABLE 5. Additional Projects Needed as Defined at the Monterey, California Meeting

\section{PRIORITY PROJECTS}

1. Chlorine Treatment Effects

2. Oxygen Concentration Effects on Aluminum

3. Calcereous Deposit Formation

4. Corrosion Fatigue on Aluminum Tubes in Sea Water

5. A Study of Borers in Concrete

6. Antifouling Marine Concrete

7. Marine Microbiofouling Study

NEEDED PROJECTS

1. Concrete Fatigue Study

2. Tropical Marine Bacterial Growth on OTEC Surfaces

3. Aluminum-Concrete Compatibility Studies

4. Open Cycle Biofouling Problems

5. Artificial Island Effects on Biota 
Ongoing Project Development Activities

There are several constraints imposed upon a discussion of ongoing project development activities. These constraints are primarily those uncertainties involved in initiating, evaluating, and contracting for needed services.

A major portion of the project development in the Transition Quarter resulted from ideas generated by the Biofouling and Corrosion Project Activity Office. In addition to the ideas developed at the Seattle meeting, other program needs as well as a re-evaluation of earlier ideas resulted from a meeting of our consultants and certain other OTEC personnel at Monterey, California. At this meeting in early June 1976 several unsolicited proposals were evaluated and the need for emphasizing work with certain materials was considered. Transition Quarter project development activities are summarized below.

- A major effort was made in this period to develop a project and find a contractor to develop an alternative biofouling measuring device. Although no unfavorable characteristics are known about the biofouling instrument developed by CMU, prudent technical and scientific practice calls for verification of the results expected from the CMU effort. This verification would have added weight if it were to be obtained by a different system employing difference scientific principles. Nine proposals were received and are under evaluation.

- Two proposals were reviewed to conduct work to define critical copper ion toxicity concentrations. These proposals are under evaluation. Work statements were prepared for projects to determine galvanic corrosion effects of concrete reinforcing steel and corrosion fatigue of aluminum. Competitive procurements procedures will be initiated in early FY-1977.

- There is interest in having research conducted on the factors influencing calcareous deposition in OTEC systems, antifouling marine concrete oxygen concentration effects on the corrosion of aluminum in ammonia, 
water biofouling tendencies, and unique methods for preventing biofouling. The possibilities of funding one or more of these projects will be considered in early FY-1977.

An ongoing assessment is being made as a part of the project development work on OTEC biofouling and corrosion to reconcile projects underway with the methodology that was established early in 1976. Figure 15 shows that the three major sectors (see page 3 ) of the OTEC biofouling and corrosion methodology are currently being compared with the nine projects underway in FY-1976 and the Transition Quarter. This comparison was made to determine the approach taken to solve the problem with the methodology.

\begin{tabular}{|c|c|c|c|c|}
\hline & PROJECT & DEFINITION & PREVENTION & ALLEVIATION \\
\hline \multirow{9}{*}{$\begin{array}{l}0 \\
\sigma \\
\sigma \\
1\end{array}$} & 1 & 0 & 0 & 0 \\
\hline & 2 & & & 0 \\
\hline & 3 & 0 & & \\
\hline & 4 & 0 & 0 & \\
\hline & 5 & 0 & & \\
\hline & 6 & 0 & 0 & \\
\hline & 7 & O & & \\
\hline & 8 & 0 & 0 & \\
\hline & 9 & 0 & 0 & \\
\hline \multirow{4}{*}{$\begin{array}{l}\mathscr{R} \\
0 \\
r\end{array}$} & 10 & 0 & 0 & 0 \\
\hline & 11 & 0 & 0 & \\
\hline & 12 & 0 & 0 & \\
\hline & 13 & 0 & 0 & \\
\hline
\end{tabular}

used to show work in a sector of the methodology.

FIGURE 15. Methodology Reconciliation 
PROJECT EVALUATION AND CONTROL PROCEDURES

This terminology is used to describe the operations undertaken to ensure that contractors conduct projects in such a manner that objectives are achieved in a timely and cost-effective manner. Basically, plans and activities in this category call for two major types of evaluation and control procedures: 1) those concerned with onsite contact, reviews and observations and 2) those involving assessment of progress and success in meeting administrative controls. Included in the former type of evaluation, fall activities such as onsite reviews of: 1) detailed project plans before studies or research are initiated, 2) routine reviews of progress about half-way through projects, and 3) visits necessitated by deviation from schedules, objectives, etc. The makeup of the visiting group will vary. It is expected that normally a member of the Project Activity Office will play a major role in such onsite visits. He may be accompanied on certain projects by a consultant, a procurement specialist, an operations office staff member, and/or ERDA member from OTEC, Washington, DC.

Administrative control will be conducted through the reading and appropriate follow-up of monthly, quarterly and final project reports. Cost monitoring will be done on a monthly basis. Contracts provide for a detailed review of the drafts of a final project report with provisions for contractor followup to any questions or comments on their work that must be handled in the final report that is submitted to ERDA through PNL. It is believed that these admiristrative procedures will help achieve objectives in a timely and cost-effective manner.

Three onsite visits were made in the reporting period to: 1) establish liaison, 2) become acquainted with key personnel, and 3) review detailed project plans. These visits were:

- Hydronautics, Inc., Laurel, Maryland, August 4, 1976 - G. A. Jensen.

- Civil Engineering Laboratory, Port Hueneme, California, August 23, 1976 - G. A. Jensen and L. D. Perrigo.

- University of Delaware, Lewes, Delaware, September 8, 1976 L. D. Perrigo. 
In the reporting period two site/project visits were made to assess progress and observe operations on the project by CMU and its subcontractor (the University of Hawaii) to develop and use a biofouling and corrosion measurement device. The first of these occurred in July to review deployment plans and to observe training excercises and the deployment operation. The second visit was made by G. A. Jensen on August 4, 1976 in Pittsburgh to become familiar with recent data from the operation of the measurement devices on the research vessel Noi'i off of Keahole Point, Island of Hawaii.

\section{BUDGETS AND COSTS}

Obligation budgets of $\$ 650,000$ and $\$ 822,000$ were established by the Division of Solar Energy for FY-1976 and the Transition Quarter, respectively. The cost ceiling for these two periods was $\$ 485,000$ with $\$ 450,982$ (92.986\%) being spent by September 30, 1976. Figure 16 is a bar chart showing these obligated amounts and those expected for FY-1977 and FY-1978. Also included in Figure 16 are data on Project Activity Office expenditures for FY-1976 and the Transition Quarter which totaled $\$ 165,817$. Office operations expenditures for FY-1977 and FY-1978 are estimated to be $\$ 300,000$ and $\$ 330,000$, respectively.

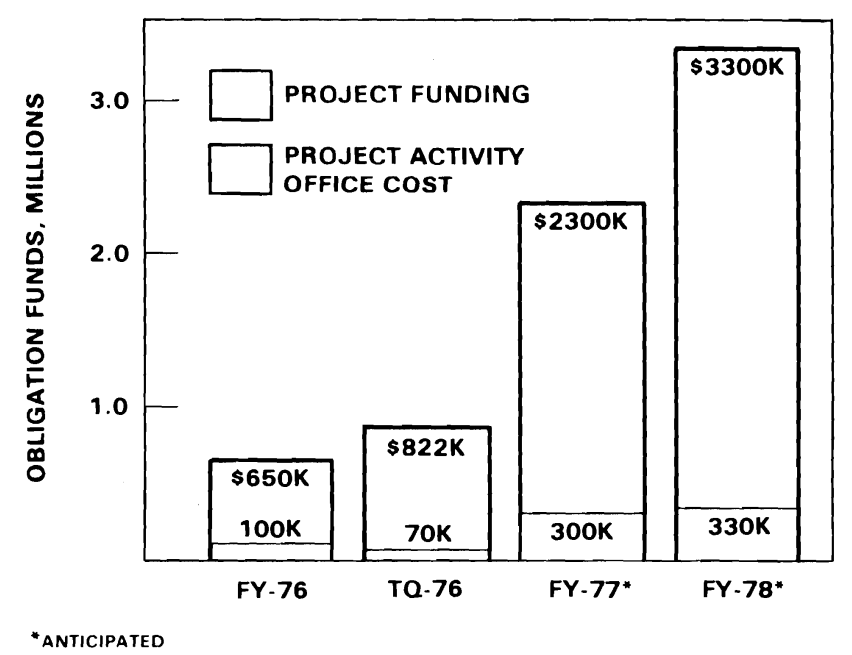

FIGURE 16. Budgets 
A summary of major project expenditures in FY-1976 and the Transition Quarter follows:

- Operation of the Project Activity Office

$\$ 97,381$

- Carnegie Mellon University [special research service agreements (SRSA) through the Chicago Operations Office, ERDA]

$\$ 231,541.00(\mathrm{a})$

- Hydronautics, Inc.

$\$ 17,764.89$

- Civil Engineering Laboratory

$\$ 6,500.00$

- University of Delaware (SRSA through Chicago Operations Office, ERDA)

$\$ 7,185.00^{(b)}$

\section{TECHNOLOGY TRANSFER}

L. D. Perrigo and G. A. Jensen of the OTEC Biofouling and Corrosion Project Activity Office prepared a paper entitled "Ocean Thermal Energy Conversion Opportunities," Battelle Report Number BNWL-SA-5808, May 1976. This paper was delivered at a Symposium on energy alternatives sponsored by the Pacific Northwest Section of the American Vacuum Society at Richland, Washington, on May 15, 1976. L. D. Perrigo and G. A. Jensen coauthored a paper entitled "Ocean Thermal Energy Conversion System Biofouling and Corrosion Problems," Battelle Report Number BNWL-SA-5970 that was delivered before the Western Region Conference, National Society of Corrosion Engineers, on September 28, 1976. Copies of both papers are available. ${ }^{(c)}$

Dr. Fetkovich of CMU and various associates coauthored and delivered two papers entitled "Heat Transfer Problems in an Ocean Thermal Power. Plant" (2) and "A Novel Method of Measuring Heat Transfer Coefficients with High Precision" (3) at the Southeastern Seminar on Thermal Sciences, University of Virginia, Charlottesville, Virginia, on June 6 through 8, 1976.

(a) An additional $\$ 13,892.46$ was costed as service assessment when these SRSA funds were transferred.

(b) Estimate. The $\$ 52,193$ to fund the University of Delaware came from ERDA Headquarters. The estimate shown is of funds actually spent by September 30, 1976.

(c) Contact L. D. Perrigo, Battelle, Pacific Northwest Laboratories, Richland, WA 99352. 
Dr. Fetkovich and his associates also coauthored and delivered a paper entitled "Studies of Biofouling in Ocean Thermal Energy Conversion Plants"(6) at the International Solar Energy Society meeting, Winnipeg, Canada, August 15-20, 1976.

Approval was sought and obtained from the Ocean Systems Branch, ERDA, to develop and sponsor a conference on OTEC biofouling and corrosion. D. B. Cash, PNL, is developing initial plans for this conference which may be held in late spring of 1977. 


\section{REFERENCES}

1. J. G. Fetkovich, Fouling and Corrosion Studies in OTEC-Related Heat Exchanger Tubes. A Progress Report, February 1976.

2. R. L. Ostrozynski and P. E. Jones, Abatement of Biofouling and Corrosion in OTEC Heat Exchangers Using Low Energy Surfaces, Final Technical Report for Period May 1, 1975-February 29, 1976. A11 ied Chemical Corporation, Buffalo, NY 14240.

3. R. R. Rothfus, Concurrent Studies of Enhanced Heat Transfer and Materials for Ocean Thermal Exchangers. Carnegie Mellon University, February 9, 1976.

4. J. G. Fetkovich et al., "Heat Transfer Problems in an Ocean Thermal Power Plant." Presented at Southeastern Seminar on Thermal Sciences, University of Virginia, Charlottesville, VA, June 6-8, 1976.

5. J. G. Fetkovich et al., "Novel Method of Measuring Heat Transfer Coefficients with High Precision." Presented at Southeastern Seminar on Thermal Sciences, University of Virginia, Charlottesville, VA, June 6-8, 1976.

6. J. G. Fetkovich, "Studies of Biofouling in Ocean Thermal Energy Conversion Plants." Presented at the International Solar Energy Society Meeting, Winnipeg, Canada, August 15-20, 1976. 
No. of

Copies

OFFSITE

1

27

1

2

ERDA Chicago Patent Group

U. S. Energy Research and

Development Administration

Argonne, IL 60439

A. A. Churm

ERDA, Division of Solar Energy

Washington, DC 20555

R. Cohen

S. Gronich

H. H. Skowbo

ERDA Technical Information Center

Battelle Columbus Laboratories

505 King Avenue

Columbus, $\mathrm{OH} 43201$

W. K. Boyd

Civil Engineering Laboratory

Port Hueneme, CA 93043

R. W. Drisko

F. L. La Que

Claridge House, Apt. 803

Claridge Drive

Verona, NJ 07044

Gilbert Associates

1828 L. Street

Washington, DC 20555

J. S. Van Summern

Naval Post Graduate School

Department of Oceanography

Monterey, CA 93940

E. C. Haderlie

Navy Facilities Engineering Command

Department of the Navy

200 Stovall Street

Alexandria, VA 22332

CDR L. K. Donovan

E. Silva 
No. of

Copies

$1 \quad$ Oklahoma State University

School of Chemical Engineering

Stillwater, OK 74074

K. J. Bell

$1 \quad$ Oregon State University

Director of Energy Research and Technology

Engineering Experiment Station

Covel Hall 219

Corvallis, OR 97331

J. G. Knudsen

1 Oak Ridge National Laboratory

Energy Division

P.0. Box $X$

Oak Ridge, TN 73830

J. Michel

ONSITE

2

ERDA - Richland Operations

N. W. Fraser

G. L. Liffick

25

Battelle-Northwest

D. B. Cash

K. K. Drumheller

C. E. Elderkin

J. W. Finnigan

C. I. Gibson

G. A. Jensen

R. F. Kenner

W. W. Laity

R. E. Nightingale

D. E. Olesen

L. D. Perrigo (10)

J. L. Simmons

Technical Information Files (3)

Technical Publications (1) 